\title{
Myocyte-Specific Enhancer Factor 2A
}

National Cancer Institute

\section{Source}

National Cancer Institute. Myocyte-Specific Enhancer Factor 2A. NCI Thesaurus. Code C92156.

Myocyte-specific enhancer factor 2A (507 aa, $55 \mathrm{kDa}$ ) is encoded by the human MEF2A gene. This protein plays a role in the regulation of both transcription and muscle development. 